Prepared in cooperation with the U.S. Army Corps of Engineers, Sacramento District

\title{
Digital Geospatial Presentation of Geoelectrical and Geotechnical Data for the Lower American River and Flood Plain, East Sacramento, California
}

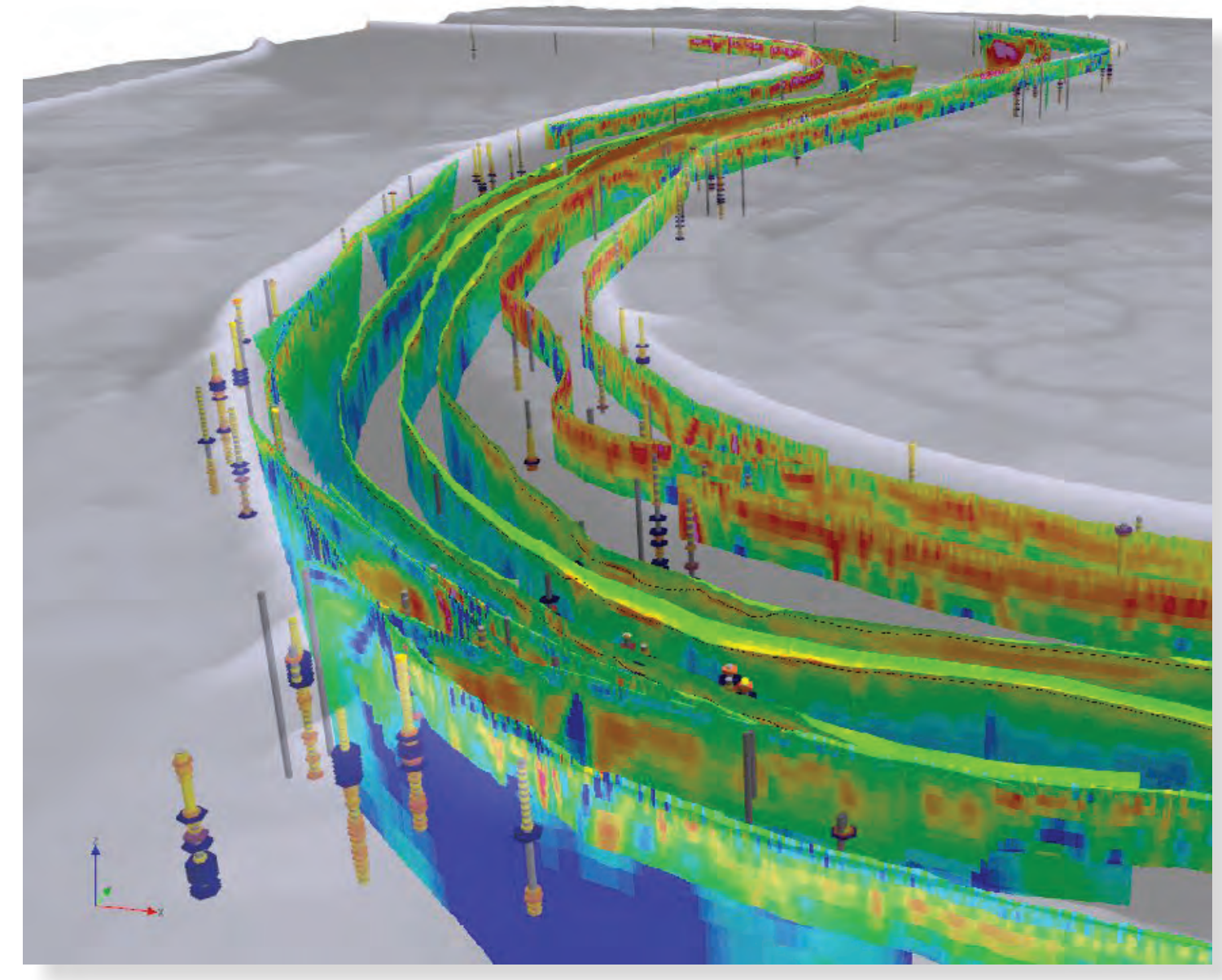

Data Series 902 
Cover. View of the three-dimensional framework for the lower American River. 


\section{Digital Geospatial Presentation of Geoelectrical and Geotechnical Data for the Lower American River and Flood Plain, East Sacramento, California}

By Lyndsay B. Ball, Bethany L. Burton, Michael H. Powers, and Theodore H. Asch

Prepared in cooperation with the U.S. Army Corps of Engineers, Sacramento District

Data Series 902 


\title{
U.S. Department of the Interior SALLY JEWELL, Secretary
}

\section{U.S. Geological Survey Suzette M. Kimball, Acting Director}

\author{
U.S. Geological Survey, Reston, Virginia: 2014
}

For more information on the USGS - the Federal source for science about the Earth, its natural and living resources, natural hazards, and the environment, visit http://www.usgs.gov or call 1-888-ASK-USGS.

For an overview of USGS information products, including maps, imagery, and publications, visit http://www.usgs.gov/pubprod

To order this and other USGS information products, visit http://store.usgs.gov

Any use of trade, firm, or product names is for descriptive purposes only and does not imply endorsement by the U.S. Government.

Although this information product, for the most part, is in the public domain, it also may contain copyrighted materials as noted in the text. Permission to reproduce copyrighted items must be secured from the copyright owner.

Suggested citation:

Ball, L.B., Burton, B.L., Powers, M.H., and Asch, T.H., 2014, Digital geospatial presentation of geoelectrical and geotechnical data for the lower American River and flood plain, east Sacramento, California: U.S. Geological Survey Data Series 902, 12 p., http://dx.doi.org/10.3133/ds902.

ISSN 2327-638X (online) 


\section{Contents}

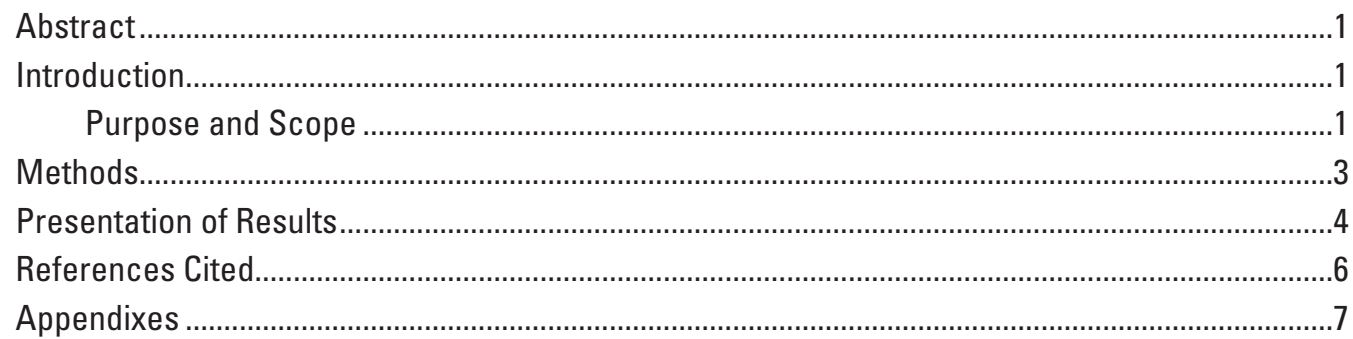

\section{Figures}

1. Location of the lower American River study reach and associated geophysical and

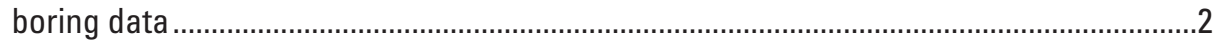

2. View of the three-dimensional framework project in Encom Discover PA Viewer

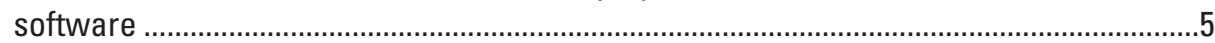

\section{Tables}

1. Summary of geoelectrical data presented in this digital release ........................................

2. Definition of Universal Soil Classific ation System symbols ............................................

3. Digital data organization for the lower American River geophysical framework and source data 


\section{Conversion Factors}

\begin{tabular}{|c|c|c|}
\hline Multiply & By & To obtain \\
\hline \multicolumn{3}{|c|}{ Length } \\
\hline foot (ft) & 0.3048 & meter (m) \\
\hline mile (mi) & 1.609 & kilometer (km) \\
\hline
\end{tabular}

Vertical coordinate information is referenced to the North American Vertical Datum of 1988 (NAVD 88).

Horizontal coordinate information is referenced to the North American Datum of 1983 (NAD 83)

Elevation, as used in this report, refers to distance above the vertical datum. 


\title{
Digital Geospatial Presentation of Geoelectrical and Geotechnical Data for the Lower American River and Surrounding Flood Plain, East Sacramento, California
}

\author{
By Lyndsay B. Ball, Bethany L. Burton, Michael H. Powers, and Theodore H. Asch
}

\begin{abstract}
To characterize the extent and thickness of lithologic units that may have differing scour potential, the U.S. Geological Survey, in cooperation with the U.S. Army Corps of Engineers, has performed several geoelectrical surveys of the lower American River channel and flood plain between Cal Expo and the Rio Americano High School in east Sacramento, California. Additional geotechnical data have been collected by the U.S. Army Corps of Engineers and its contractors. Data resulting from these surveys have been compiled into similar database formats and converted to uniform geospatial datums and projections. These data have been visualized in a digital three-dimensional framework project that can be viewed using freely available software. These data facilitate a comprehensive analysis of the resistivity structure underlying the lower American River corridor and assist in levee system management.
\end{abstract}

\section{Introduction}

The lower American River corridor in east Sacramento, California, serves a variety of functions. The American River provides several fundamental ecosystem services, including habitat for Pacific salmon (Merz and Vanicek, 1996) and the federally threatened elderberry longhorn beetle (Lang and others, 1989). The river and flood plain also serve as popular recreation areas for local residents, providing parks, bike/pedestrian trails, and boating and fishing opportunities. Finally, the corridor is a causeway for floodwaters, and the levee system defining the modern boundary of the river corridor provides critical flood protection for the city of Sacramento and surrounding suburban development.

The American River levees bound a flood plain underlain by a mixed lithology of alluvial and hydraulic mining deposits that vary in thickness but may reach up to $80 \mathrm{ft}$ (Helley and Harwood, 1985). Sand deposits have been observed to be preferentially prone to scour during floods, whereas some lithologic packages in the river channel have been observed to resist scour. Scour-prone lithologic packages have the potential to compromise the levee system and require mitigation. An improved understanding of the geometry and scour potential of major lithologic packages underlying the lower American River and its flood plain may facilitate more strategic management of the levee system and the river corridor's other functions.

Traditionally, exploration of lithologic and geotechnical properties is accomplished through borehole drilling, allowing subsurface materials to be directly observed, described, and tested. Extensive drilling has been conducted on the lower American River corridor, resulting in high vertical-resolution data sets describing the lithology and stiffness of the sediments. Although types of data are invaluable, their inherently one-dimensional nature makes upscaling to a more manageable regional interpretation difficult. Surface geophysical data can provide supporting information about the variability of subsurface physical properties that may be correlated to changes in lithology or scour potential. Borehole data provide high-resolution data about the vertical distribution of properties, surface geophysical data can provide supplemental data about vertical and lateral variations in physical earth properties. Geoelectrical methods measure the resistivity of the subsurface. The resistivity of a given material is controlled primarily by water content and quality, and also by the presence of clays or other conductive minerals. Changes in resistivity structure therefore reflect changes in porosity/compaction, lithologic texture, degree of saturation, groundwater composition, cementation, and degree of weathering/fracturing.

\section{Purpose and Scope}

To assist the U.S. Army Corps of Engineers (USACE) with the management of the lower American River levee system, the U.S. Geological Survey (USGS) has completed three surface geophysical surveys to explore the resistivity structure of the American River flood plain and channel (fig. 1). These surveys were conducted on the 5.5 -mile reach between $\mathrm{Cal}$ Expo (near river mile 5.5) and the Rio Americano High School (near river mile 11). This reach has been identified by USACE 

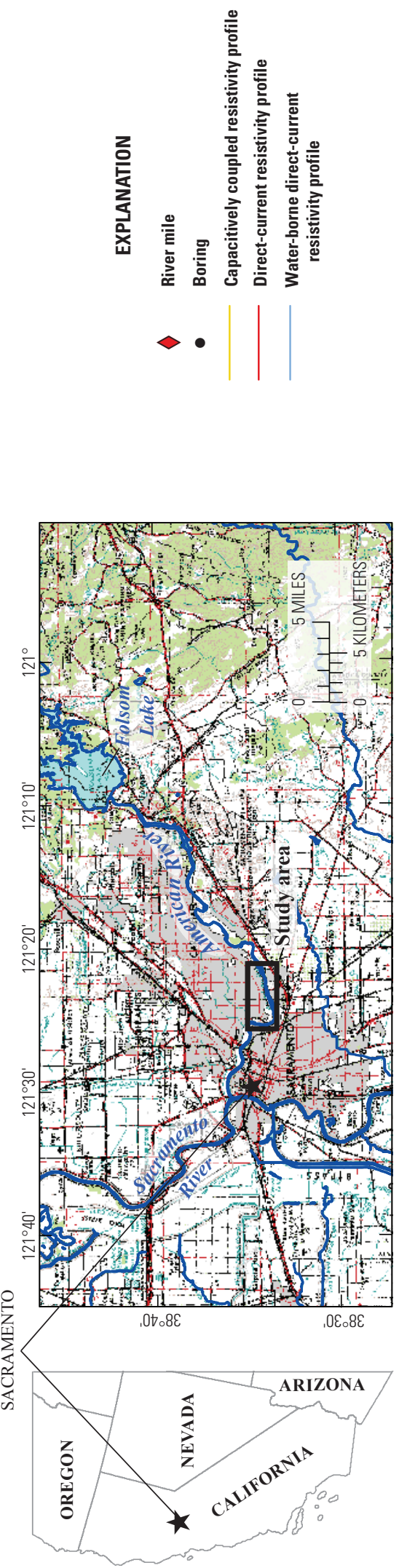

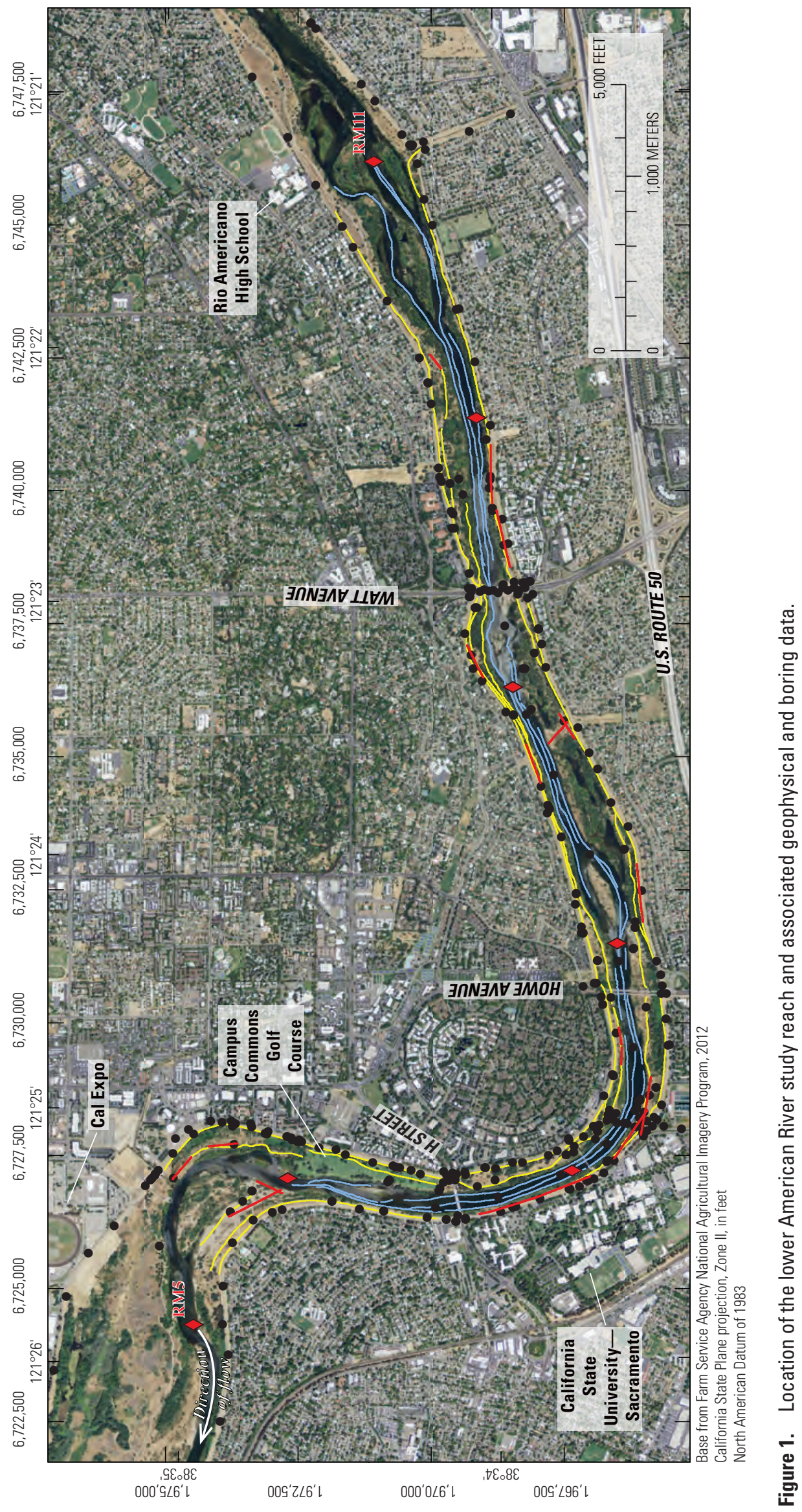


as a priority levee management area. Preceding reports document the methods and results of each survey (table 1; Asch and others, 2008; Ball and Teeple, 2013; Burton and others, 2014). The combined results of these surveys are released in this report as digital data in a three-dimensional (3-D) framework that allows geospatial comparison between the geophysical results and available geotechnical and lithologic data. This report does not present formal interpretations of these data sets. Summary of geoelectrical data presented in this digital release. The full reports provide details on the methods and results of each survey.

\section{Methods}

Geoelectrical data were collected by the USGS during three field campaigns between 2007 and 2011 using a combination of techniques that characterize subsurface resistivity (table 1). Galvanic and capacitive resistivity techniques consisted of land-based direct-current (DC) resistivity (Asch and others, 2008; Burton and others, 2014), water-borne DC continuous resistivity profiling (CRP) (Ball and Teeple, 2013), and capacitively coupled (CC) CRP (Asch and others, 2008; Burton and others, 2014). These data have been included in the framework presented in this report. Frequency-domain multi-frequency (Asch and others, 2008) and multi-offset electromagnetic (EM) induction data (Burton and others, 2014) were also acquired during field surveys. The single receiver coil, multi-frequency EM data suffered from low electromagnetic response levels, high ambient electromagnetic noise, and large system drifts, all of which precluded useful inversions (Asch and others, 2008). Although this would not be as large a problem in conductive terrain, the high-resistivity nature of the materials underlying the lower American River creates a non-ideal environment for using small induction number EM profiling systems. Most of the single-frequency, multi-offset receiver coil EM data are located along the same profile paths as the left bank CC CRP data and do not provide additional site coverage. Because the purpose of the framework is to provide a spatially comprehensive and interpretable view of the resistivity structure of the study reach using the best-available data, the EM data were excluded from the framework.

Resistivity measurements are made by transmitting current into the subsurface and measuring the resulting voltage at the ground surface. Traditionally, individual resistivity measurements are made using a set of four electrodes (two current electrodes and two potential electrodes), known as an array, to make a measurement. As larger distances are placed between electrodes, the depth of investigation increases. Modern resistivity profiling typically uses a large number of steel electrodes hammered into the ground and connected through multiconductor cables to a digital meter. The meter is programmed to switch between many different combinations of current and potential electrode pairs, creating a cross section of apparent resistivity measurements. Advanced resistivity meters contain multiple data channels, allowing simultaneous voltage measurements to be made between potential electrodes with various spacings using a single current transmission from two current electrodes. Therefore, the resistivity at multiple depth intervals can simultaneously be determined.

When electrical contact with the subsurface can be established without hammering steel stakes into the ground, such as by submerging the multiconductor cable in water or developing an electric field through capacitance, data can be collected while the electrode array is slowly pulled using the CRP technique. The CRP technique allows rapid data collection with high lateral resolution, but this technique has a more limited depth-of-investigation and can often be more susceptible to site-related noise when compared to traditional resistivity profiling. For these reasons, both CRP and traditional resistivity profiling techniques were used at the lower American River.

The data-collection and processing methods and results of each survey are discussed in detail in individual reports and are briefly summarized here: The 2007 survey focused on characterization of the right bank of the flood plain between the Campus Commons golf course and the Rio Americano High School (Asch and others, 2008). The CC CRP data were collected using a single capacitive current dipole cable paired with several potential dipole cables towed behind an all-terrain vehicle. The CC CRP technique allowed the collection of long, shallow resistivity profiles (depth of investigation $=15$ to 45 feet [ft]) that cover nearly the entire length of the study area and often include multiple passes along the width of the flood plain (fig. 1). These long profiles were supplemented with shorter segments of traditional DC resistivity data in selected areas to characterize deeper resistivity structure (depth of investigation $=60$ to $210 \mathrm{ft}$ ) and to evaluate the influence of urban noise and signal strength in the $\mathrm{CC}$ resistivity results.

Table 1. Summary of geoelectrical data presented in this digital release.

[The full reports provide details on the methods and results of each survey. CC, capacitively coupled; DC, direct-current; river banks are described relative to the direction of flow]

\begin{tabular}{llll}
\hline \multicolumn{1}{c}{ Survey date } & \multicolumn{1}{c}{ Type of data collected } & Location & Full report \\
\hline May 2007 & CC resistivity, ground DC resistivity & Right bank & Asch and others, 2008 \\
May-June 2008 & Water-borne DC resistivity & River channel & Ball and Teeple, 2013 \\
June 2011 & CC resistivity, ground DC resistivity & Left and right banks & Burton and others, 2014 \\
\hline
\end{tabular}


Digital Geospatial Presentation of Geoelectrical and Geotechnical Data for the Lower American River and Flood Plain

The 2008 survey used a water-borne CRP technique of the DC resistivity method to characterize the river channel, where data were collected while towing a 13-electrode array behind a boat. By using this technique, nearly continuous, moderately deep resistivity profiles (depth of investigation $=$ $65 \mathrm{ft}$ ) were acquired along three passes of the American River channel (Ball and Teeple, 2013). In 2011, a nearly identical approach to that taken in 2007 (combining CC CRP and traditional DC resistivity profiling) was applied to the entire left bank and the right bank downstream of the Campus Commons golf course (Burton and others, 2014).

Data from all surveys were positioned using sub-meter accuracy global positioning systems, although heavy tree cover in some parts of the flood plain resulted in a loss of satellite reception. In these areas, data were interpolated between well-positioned locations assuming a uniform CRP towing speed. Apparent resistivity measurements from each survey were inverted in commercial software using similar processing schematics to estimate the heterogeneous resistivity structure and are discussed in detail in the individual survey reports (Asch and others, 2008; Ball and Teeple, 2013; Burton and others, 2014). To maintain consistency between survey years and to insure that the best processing methods available were used, CC CRP data from the 2007 right-bank surveys were fully reprocessed and inverted to follow the same procedures used for the 2011 left bank survey (Burton and others, 2014).

To prepare the digital data for this release, inverted resistivity models from each survey were compiled into databases specific to each method. A uniform projected coordinate system (California State Plane, zone II) and horizontal datum (North American Datum of 1983) were applied to all databases. A uniform vertical datum (North American Vertical Datum of 1988) was established using a 9-ft resolution grid of bare-earth corrected light detection and ranging (lidar) data and river bathymetric surveys provided by USACE (Lewis Hunter, USACE, written commun., February 2012). The integration of these three surveys provides comprehensive characterization of the resistivity structure of the study reach.

Extensive boring data have also been provided by USACE and include both lithologic and geotechnical data (Lewis Hunter and Michael Kynett, USACE, written communs., February and October 2012). Boring data have been complied into digital databases and projected into the same geospatial coordinate system and datums as the geophysical data. Lithologic materials have been described using the Universal Soil Classification System categories commonly applied to engineering problems (table 2) (American Society of Testing and Materials, 1985). Geotechnical data consist of estimations of soil stiffness (N-value or blow count) from a variety of methods including cone-penetrometer (CPT) and standard-penetrometer (SPT) in-situ testing. For the "CF" series of borings, corrected N160 values were used to represent the N-value. Data intervals displayed in the framework are limited to the tested interval only, as described by the sample length in the original database. Non-numerical
Table 2. Definition of Universal Soil Classification System symbols (American Society of Testing and Materials, 1985).

\begin{tabular}{|c|c|}
\hline Symbol & Definition \\
\hline G & Gravel \\
\hline S & Sand \\
\hline M & Silt \\
\hline $\mathrm{C}$ & Clay \\
\hline $\mathrm{O}$ & Organic matter \\
\hline $\mathrm{P}$ & Poorly graded (uniform particle sizes) \\
\hline W & Well-graded (diverse particle sized) \\
\hline $\mathrm{H}$ & High plasticity \\
\hline $\mathrm{L}$ & Low plasticity \\
\hline
\end{tabular}

reported values suggesting that resistance was met, such as "R" or high blow counts for intervals less than 6 inches, were given an $\mathrm{N}$-value of 150 for visualization. These boring data are the foundation for creating meaningful interpretations of lithologic and scourability variations in the subsurface using the resistivity data.

\section{Presentation of Results}

Data are provided in two formats (table 3). The primary format is a 3-D framework project that has been prepared using Encom Discover Profile Analyst (PA) software (Pitney Bowes, North Sydney, Australia) (3DFRAMEWORK directory). This project provides a geospatially referenced environment where the geophysical and boring data can be viewed, zoomed, rotated, and toggled on and off (fig. 2). Encom Discover PA Viewer software can be freely downloaded from Pitney Bowes (http://www.pitneybowes.com/pbencom/support/ product-downloads.html). Once installed, the project may be opened from the viewer program by selecting the AmRiv3DFramework.egs project file. The 3-D visualization can be computationally expensive and may take several minutes to load on some systems.

Table 3. Digital data organization for the lower American River geophysical framework and source data.

\begin{tabular}{cl}
\hline \multicolumn{1}{c}{ Directory } & \multicolumn{1}{c}{ Contents } \\
\hline 3DFRAMEWORK & $\begin{array}{l}\text { Digital framework project and supporting } \\
\text { files. }\end{array}$ \\
SOURCE_DATA & $\begin{array}{c}\text { Databases of the inverted resistivity profiles } \\
\text { and boring data in ASCII standard (*.xyz, } \\
\text { *.csv) and Geosoft Oasis montaj (*.gdb, } \\
\text { http://www.geosoft.com/) database formats. }\end{array}$ \\
\hline
\end{tabular}




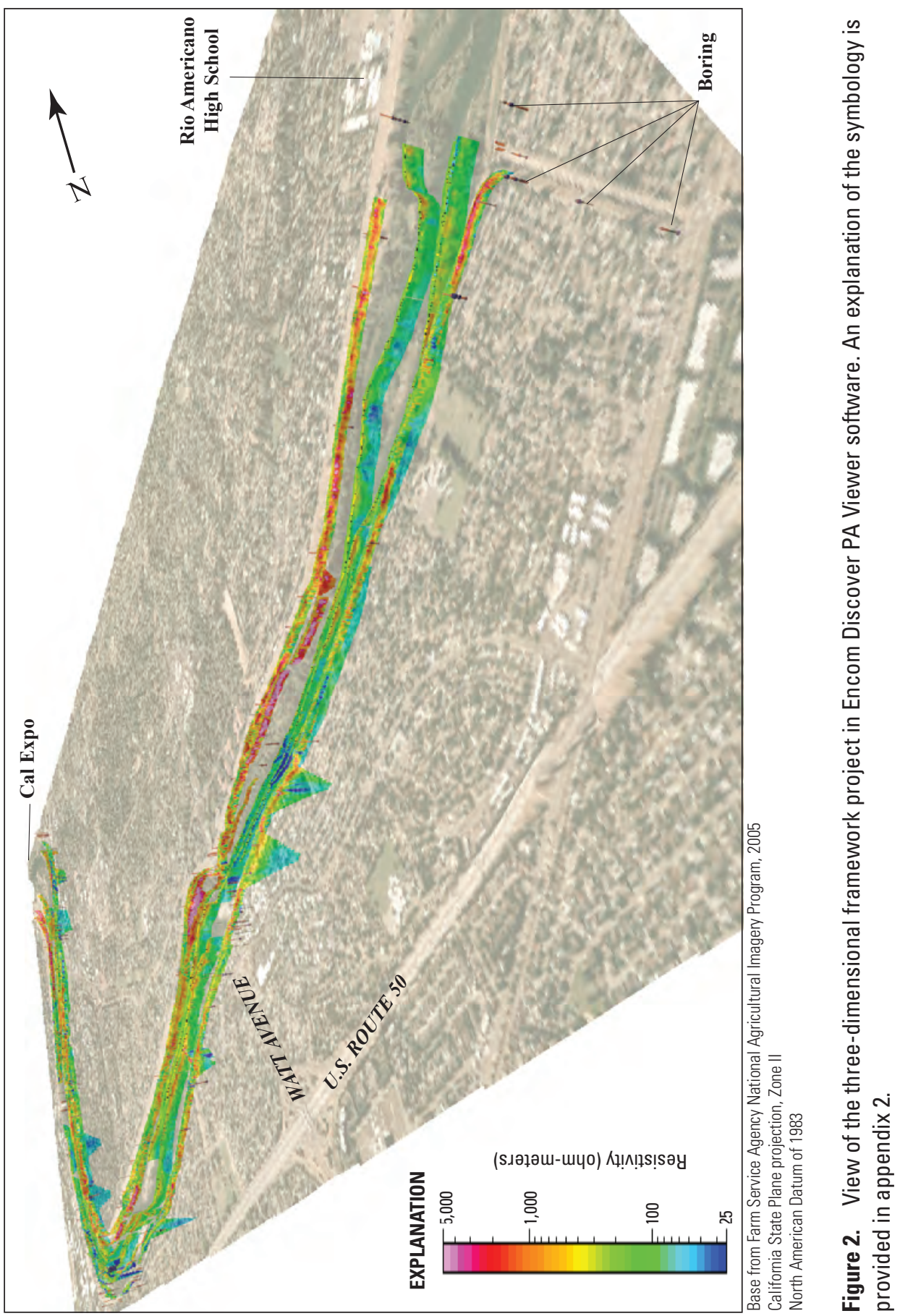


The 3DFRAMEWORK directory (available at $h t t p: / /$ pubs.usgs.gov/ds/0902/downloads/3DFRAMEWORK.zip) contains many additional source files necessary to run the project, and the project session may become corrupted if the files in the directory are modified. The databases used to generate the framework project are provided in a separate directory (SOURCE_DATA directory; available at $h t t p: / /$ pubs.usgs.gov/ds/0902/downloads/SOURCE_DATA.zip) and described in detail in appendix 1. It is highly recommended that these source databases be used to the view the data in other software platforms instead of accessing the files stored in the 3DFRAMEWORK directory. The resistivity structure as a function of depth along the geophysical profiles is given in an array matrix format, where indexes are used to match corresponding depth and resistivity values. To facilitate comparison of the inverted resistivity profiles to other data beyond the geophysical lines, such as borehole lithology or remote sensing data, land-surface elevations in the resistivity profile and boring databases have been sampled from the 9-ft-resolution lidar-derived digital-elevation model referenced to NAVD88.

An explanation of the digital data structure and contents of this report are in appendix 1. A graphic explanation to the symbology used in the framework project is provided in appendix 2 .

\section{References Cited}

American Society of Testing and Materials, 1985, Classification of soils for engineering purposes: Annual Book of ASTM Standards, v. D 2487-83, p. 395-408.

Asch, T.H., Deszcz-Pan, M., Burton, B.L., and Ball, L.B., 2008, Geophysical characterization of the American River levees, Sacramento, California, using electromagnetic, capacitively coupled, and direct-current resistivity: U.S. Geological Survey Open-File Report 2008-1109, 12 p.

Ball, L.B., and Teeple, A.P., 2013, Characterization of major lithologic units underlying the lower American River using water-borne continuous resistivity profiling, Sacramento, Calif., June 2008: U.S. Geological Survey Open-File Report 2013-1050, $13 \mathrm{p}$.

Burton, B.L., Powers, M.H., and Ball, L.B., 2014, Characterization of subsurface stratigraphy along the lower American River floodplain using electrical resistivity: Sacramento, Calif., 2011: U.S. Geological Survey Open-File Report 2014-1242, 642 p.

Helley, E.J., and Harwood, D.S., 1985, Geologic map of the late Cenozoic deposits of the Sacramento Valley and northern Sierran Foothills, California: U.S. Geological Survey Map MF-1790, scale 1:62,500, 24 p.

Lang, F.J., Jokerst, J.D., and Sutter, G.E., 1989, Habitat and populations of the valley elderberry longhorn beetle along the Sacramento River: U.S. Department of Agriculture Forest Service General Technical Report PSW-110, p. 242-248.

Merz, J.E., and Vanicek, C.D., 1996, Comparative feeding habits of juvenile salmon, steelhead, and Sacramento squawfish in the lower American River, California: California Fish and Game, v. 82, no. 4, p. 149-159. 
Appendixes 


\section{Appendix 1.}

Explanation of digital data structure and content.

\section{Contents}

Directory:

3DFRAMEWORK

SOURCE_DATA

\section{Contents:}

Encom Discover PA project (and associated files) showing a 3-D map containing resistivity profiles, available borehole lithology and geotechnical test data, and lidar-based digital elevation model.

Source databases used to compile the Encom PA projects in the 3D framework directory.

\section{Geospatial Information}

Horizontal Coordinate System:

California State Plane projection

Zone 2

North American Datum of 1983 (NAD83)

Units: feet

Vertical Coordinate System:

North American Vertical Datum of 1988 (NAVD88)

Units: feet

Vertical positions are referenced to the 9-feet resolution lidar-based digital elevation model provided by the U.S. Army Corps of Engineers Sacramento District.

\section{Data Organization}

Data are provided in ASCII (*.xyz) and Geosoft geodatabase (*.gdb) formats (SOURCE_DATA directory). ASCII data can be read with text-editing software; Geosoft geodatabases can be viewed using the Oasis montaj viewer software freely distributed by Geosoft (http://www.geosoft.com/support/downloads/viewers/oasis-montaj-viewer).

The provided databases and grids are also presented in a 3-D framework project for the lower American River and surrounding flood plain between Cal Expo and the Rio Americano High School (3DFRAMEWORK directory). This framework project has been prepared using Encom PA version 12.0 and can be viewed using the PA Viewer freely distributed by Encom Discover PA (http://www.pitneybowes.com/pbencom/support/product-downloads.html). Symbology used in the framework project is explained in appendix 2. 


\section{Data Information}

\section{SUBFOLDER: USGS_SECTIONDATA}

DATABASE: AmRiv_USGS_DCLines.gdb

Description: Land-based direct-current (DC) resistivity section data collected by the U.S. Geological Survey (USGS) on left and right banks of the American River in 2007 (Asch and others, 2007) and 2011 (Burton and others, 2014).

$\begin{array}{ll}\text { Channel heading: } & \text { Description: } \\ \text { CHORDLEN } & \text { Chord length with respect to geospatial distance } \\ \text { DEM_9ft } & \text { LiDAR-derived surface digital elevation model, in feet } \\ \text { depth_ft } & \text { Depth of resistivity data point, in feet, [i]=array index } \\ \text { Dist_ft } & \text { Along-profile distance, in feet } \\ \text { GPSElev_ft } & \text { Orthometric NAVD88 GPS-derived surface elevation, in feet } \\ \text { Rho_ohmm } & \text { Inverted resistivity, in ohm meters (ohm-m), [i]=array index } \\ \text { x_NAD83CASPz2_USft } & \text { Easting, in feet } \\ \text { y_NAD83CASPz2_USft } & \text { Northing, in feet } \\ \text { Year } & \text { Survey year }\end{array}$

DATABASE: AmRiv_USGS_MarineDCLines.gdb

Description: Water-borne direct-current (DC) resistivity section data collected by USGS in the American River channel in 2008 (Ball and Teeple, 2013).

Channel heading:

CHORDLEN

DEM 9ft

depth_ft

Distance $\mathrm{ft}$

H20_depth_ft

LineNum

Rho ohmm

x_NAD83CASPz2_USft

y_NAD83CASPz2_USft

z_NAVD88_ft

Year
Description:

Chord length with respect to geospatial distance

lidar-derived surface digital elevation model, in feet

Depth of resistivity data point, in feet, [i]=array index

Along-profile distance, in feet

Water depth derived from bathymetric echosounder, in feet

Original 2008 line number

Inverted resistivity, in ohm-m, [i] $=$ array index

Easting, in feet

Northing, in feet

Water surface elevation, in feet (approximated above LiDAR with controls at river mile 6 and 11 using bathymetric data)

Survey year 


\section{DATABASE: AmRiv_USGS_CCLines.gdb}

Description: Capacitively coupled resistivity section data collected by USGS on the left and right banks of the American River in 2007 (Asch and others, 2007) and 2011 (Burton and others, 2014).

Channel heading

CHORDLEN

DEM_9ft

depth_ft

Dist_ft

FileName

Rho_ohmm

x_NAD83CASPz2_USft

y_NAD83CASPz2_USft

Year

\section{Description}

Chord length with respect to geospatial distance

lidar-derived surface elevation, in feet

Depth of resistivity data point, in feet, [i]=array index

Along-profile distance, in feet

Original segment file name

Inverted resistivity, in ohm-m, [i]=array index

Easting, in feet

Northing, in feet

Survey year

\section{SUBFOLDER: USACE_BORINGDATA}

DATABASE: AmRivBoring_Collar.gdb, AmRivBoring_Lith.gdb, AmRivBoring_Nint.gdb

Description: Borehole lithologic and water table data provided by USACE.

\begin{tabular}{|c|c|}
\hline Channel heading & Description \\
\hline DH_Hole & Hole name \\
\hline DH_East & Easting, in feet \\
\hline DH_North & Northing, in feet \\
\hline DH_RL & Relative level referenced to lidar-derived elevations where available, in feet \\
\hline DH_Dip & Borehole dip angle, in degrees \\
\hline DH_Azimuth & Borehole-deviation direction, in degrees \\
\hline DH_Top & Top depth of borehole, in feet \\
\hline DH_Bottom & Borehole total depth, in feet \\
\hline DH_From & Starting depth of interval for from-to data, in feet \\
\hline DH_To & Bottom depth of interval for from-to data, in feet \\
\hline DH_Depth & Depth of point data, in feet \\
\hline DEM9ft & lidar-derived surface elevation, in feet \\
\hline USACEElev & Original elevations assigned in database \\
\hline Mask & Book-keeping channel \\
\hline Graphic & Universal Soil Classification lithologic code \\
\hline Descrip & Lithologic description \\
\hline Length & Sample interval, in feet \\
\hline Recovery & Recovered sample, in feet \\
\hline Type & Sample type \\
\hline $\mathrm{N}$ & Number of blows, corrected $\mathrm{N}_{1(60)}$ used where available \\
\hline
\end{tabular}




\section{Disclaimers}

The USGS reserves the right to revise the data pursuant to further analysis and review. Furthermore, the data are released on condition that neither the USGS nor the U.S. Government may be held liable for any damages resulting from its authorized or unauthorized use.

Although these data have been processed successfully on a computer system at the USGS, no warranty, expressed or implied, is made regarding the display or utility of the data on any other system, for general or scientific purposes, nor shall the act of distribution constitute such warranty. The USGS shall not be held liable for improper or incorrect use of the data described or contained herein.

Although this information product, for the most part, is in the public domain, it may also contain copyrighted materials. Permission to reproduce copyrighted items for other than personal use must be secured from the copyright owner.

Any use of trade, product, or firm names is for descriptive purposes only and does not imply endorsement by the USGS or the U.S. Government.

\section{References}

Asch, T.H., Deszcz-Pan, M., Burton, B.L., and Ball, L.B., 2008, Geophysical characterization of the American River levees, Sacramento, California, using electromagnetic, capacitively coupled, and direct-current resistivity: U.S. Geological Survey Open-File Report 2008-1109, 12 p., 3 appendices, 11 plates. [Also available at http://pubs.usgs.gov/of/2008/1109/.]

Ball, L.B., and Teeple, A.P., 2013, Characterization of major lithologic units underlying the lower American River using waterborne continuous resistivity profiling, Sacramento, California, June 2008: U.S. Geological Survey Open-File Report 20131050, 13 p., 5 plates. [Also available at $h t t p: / / p u b s . u s g s . g o v / o f / 2013 / 1050 /$.

Burton, B.L., Powers, M.H., and Ball, L.B., 2014, Characterization of subsurface stratigraphy along the lower American River floodplain using electrical resistivity and electromagnetics, Sacramento, California, 2011: U.S. Geological Survey Open-File Report 2014-1242, 42 p. [Also available at http://pubs.usgs.gov/of/2014/1242/.] 


\section{Appendix 2.}

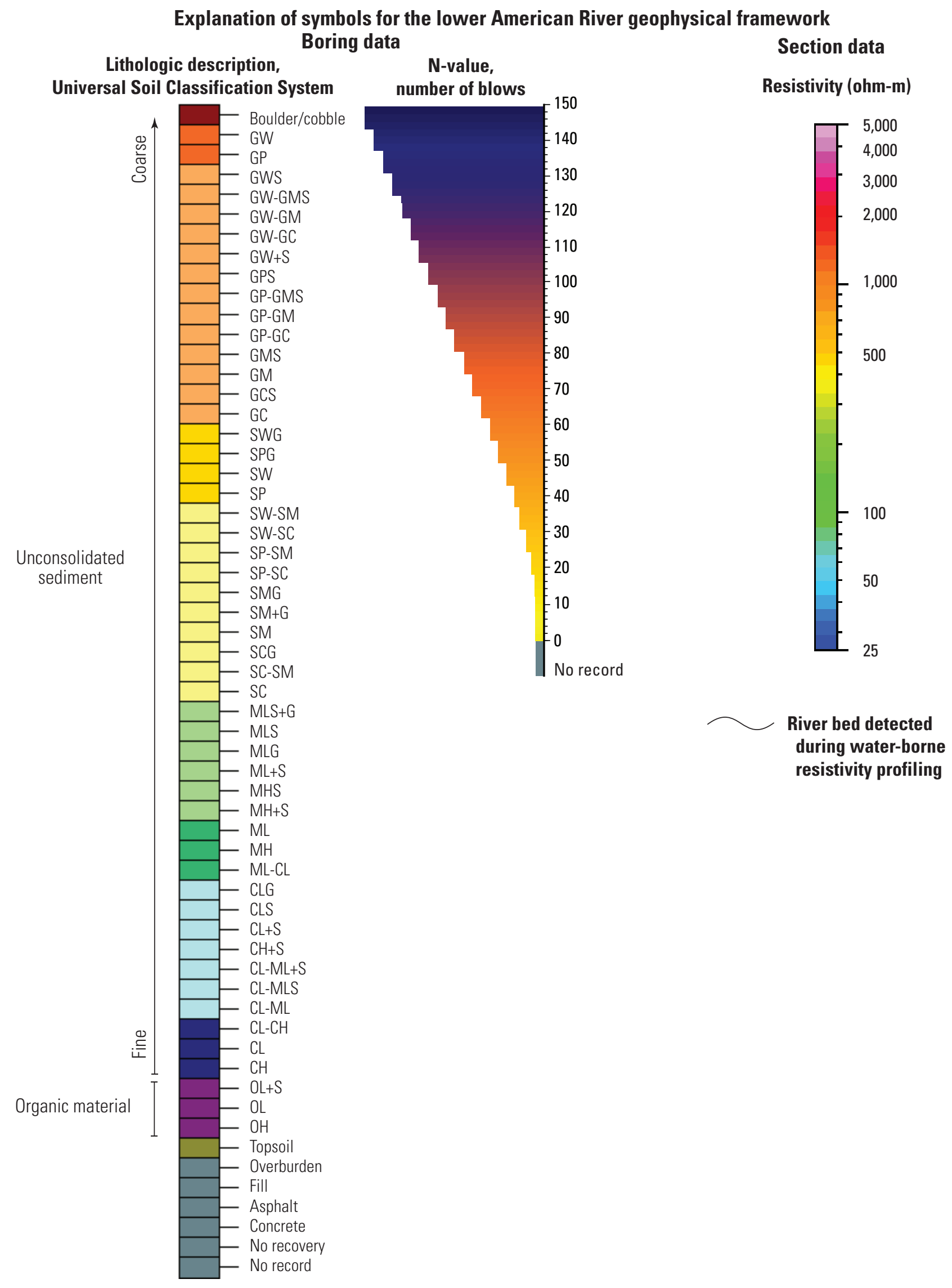


Publishing support provided by:

Denver and Rolla Publishing Service Centers

For more information concerning this publication, contact: USGS Crustal Geophysics and Geochemistry Science Center Federal Center, Box 25046, Mail Stop 964

Denver, CO 80025-0046

Or visit the Crustal Geophysics and Geochemistry Science Center Web site at:

http://crustal.usgs.gov/ 
$\stackrel{\square}{\underline{\underline{O}}}$

语

훙

ISSN 2327-638X (online) 